Materiales de Construcción

Vol. 69, Issue 333, January-March 2019, e177

ISSN-L: 0465-2746

https://doi.org/10.3989/mc.2019.09517

\title{
Urban structure degradation caused by growth of plants and microbial activity
}

\author{
E. Mejía ${ }^{\mathrm{a}} \bowtie$, J.I. Tobón ${ }^{\mathrm{b}}$, W. Osorio ${ }^{\mathrm{c}}$ \\ a. Institución Universitaria Pascual Bravo - Facultad de Ingeniería- Grupo de Investigación GIIAM (Medellin-Colombia) \\ b. Cement and Building Materials Research Group, Departamento de Materiales y Minerales, Facultad de Minas, \\ Universidad Nacional de Colombia, Sede Medellín, (Medellín, Colombia) \\ c. Soil Microbiology Research Group, Escuela de Biociencias, Facultad de Ciencias, Universidad Nacional de Colombia, \\ Sede Medellín, (Medellín, Colombia) \\ \erica.mejia@pascualbravo.edu.co
}

Received 20 September 2017 Accepted 28 May 2018

On line first 31 January 2019

\begin{abstract}
The purpose of this study was to isolate microorganisms associated to surface-affected concrete structures and to measure the in vitro dissolution of concrete based on the release of elements such as calcium and silicon. Although many microorganisms were detected only a fungus was capable of significantly decreasing the culture medium $\mathrm{pH}$ and releasing both elements. The molecular characterization allowed to identify the microorganism as Aspergillus carbonaurius, a citric-acid producing fungus that dissolved concrete in the in vitro test. After seven days of incubation, the soluble calcium concentration in the uninoculated culture medium containing concrete was $172.3 \mathrm{mg} / \mathrm{L}$, while in the inoculated medium it was $525.0 \mathrm{mg} / \mathrm{L}$. The soluble silicon concentration in the uninoculated medium was $10.3 \mathrm{mg} / \mathrm{L}$, while in the inoculated medium it was $50.1 \mathrm{mg} / \mathrm{L}$. These findings showed that plants and microorganisms rendered a synergistic effect accelerating the biodeterioration of concrete.
\end{abstract}

KEYWORDS: Concrete; Organic acids; Weathering; Waste treatment; Durability

Citation/Citar como: Mejía, E.; Tobón, J.I.; Osorio, W. (2019) Urban structure degradation caused by growth of plants and microbial activity. Mater. Construcc. 69 [333], e177 http://doi.org/10.3989/mc.2019.09517

RESUMEN: Degradación de estructuras urbanas generada por crecimiento de plantas y actividad microbiana. El objetivo de este estudio fue aislar microorganismos de la superficie de estructuras urbanas de concreto deterioradas y medir su capacidad para disolver in vitro muestras de concreto, basada en la liberación de elementos como el calcio y el silicio. De todos los microorganismos aislados sólo un hongo fue capaz de disminuir el pH y disolver el concreto. Este hongo fue identificado a nivel molecular como Aspergillus carbonaurius, un productor de ácido cítrico. Después de siete días de incubación, se encontró que la concentración de calcio soluble en el medio de cultivo no inoculado fue $172,3 \mathrm{mg} / \mathrm{L}$, mientras que en el medio inoculado era de $525,0 \mathrm{mg} / \mathrm{L}$. La concentración de silicio soluble en el medio no inoculado fue de $10,3 \mathrm{mg} / \mathrm{L}$, mientras que en el medio inoculado fue de 50,1 mg/L. Estos hallazgos mostraron que las plantas y los microorganismos producen un efecto sinérgico que acelera el biodeterioro del concreto.

PALABRAS CLAVE: Hormigón; Ácidos orgánicos; Envejecimiento; Tratamiento de residuos; Durabilidad

ORCID ID: E. Mejía (http://orcid.org/0000-0002-2913-1181); J.I. Tobón (http://orcid.org/0000-0002-1451-1309); W. Osorio (http://orcid.org/0000-0002-0654-1399)

Copyright: (C) 2019 CSIC. This is an open-access article distributed under the terms of the Creative Commons Attribution 4.0 International (CC BY 4.0) License 


\section{INTRODUCTION}

Concrete is one of the strongest materials used in the construction industry (1), however, it can be deteriorated by various environmental factors, and biological agents (2). The alteration and weathering of concrete, by natural and anthropogenic impacts, influence various physical, chemical and biological damage factors (3-5). These factors play an important role in mass loss processes, discoloration, and structural cracking (5). In this way, it is important to know that microorganisms are considered the oldest forms of life, capable of living in hostile environments (6), and they may influence weathering processes (7) by catalyzing various reactions (8) as secretion of enzymes and corrosive metabolites e.g., acids that can react with the binding material of concrete surface (9). The major biodeterioration of stones in architectural structures, monuments, buildings, and other structures (10) are generated by organic and inorganic acids which are produced by microorganisms present in concrete (6), however it is still unclear which are the species/genus of microorganisms that produce this biodeterioration and the mechanisms that take place.

In this fashion, deterioration of historical structures, valuable buildings, and other constructions represents a significant economic loss because it can affect the structural integrity and aesthetics $(9,11)$. Therefore, the research in concrete biodeterioration is receiving attention recently (12-14). The strategies to mitigate biodeterioration consist in changing the local environment, modification of concrete microstructure, nanomaterial-incorporated coatings (14), and superficial treatments, among others $(16,17)$. However, the effectiveness of these methods is not satisfactory yet $(19,20)$.

The biodeterioration includes several reactions such as chemical- and physical-alteration that allows the availability of nutrients for alkaline-tolerant microorganisms and the consequently colonization of them, as explained by Wei et al. (18). Then, pH decrease on the surface due to the acid production, that is generated by microbial metabolism which in turn favors conditions for new colonization events (16). In other words, small amounts of organic acids can facilitate the microbial growth on the surface of concrete and its biodeterioration (15). The protons react with cementitious material resulting in further functional or structural problems $(1,17)$.

The effect of the microbial growth on concrete surfaces could be influenced by the variation of concrete composition and the availability of nutrients, which depends on concrete mineral composition $(12,21)$. The studies on chemical and mineralogical composition of concretes have demonstrated that these materials commonly contain $\mathrm{Ca}, \mathrm{Mg}, \mathrm{Fe}$, $\mathrm{Mn}, \mathrm{Zn}, \mathrm{Si}, \mathrm{Al}$, and $\mathrm{Na}$, which are the composing elements of various minerals such as quartz, calcite, wollastonite, albite, anatase, and actinolite (22, 23 ), that are commonly present in mineral additions and aggregates, and hydrated calcium silicates, aluminosilicates, calcium hydroxide, calcium sulfoaluminates, among others (present in the cementing matrix) (23-25).

The concrete biodeterioration process is particularly relevant, given the large amount of existing buildings, monuments, and different structures that have been exposed to aggressive environments for long periods of time $(3,26,27)$. Therefore, it is necessary to establish control measures to mitigate the impact of biodeterioration $(16,17)$. Even though some efforts have been made to understand the biodeterioration mechanisms on urban structures, it is still unknown which species of the microorganisms can produce the greatest deterioration and which are associated to certain plants in this process.

Moreover, higher plants that establish in urban structures can also generate structural damages, but it has not been fully studied (Figure 1). However, planting concrete as an ecological concrete was conducive to prevent soil erosion and desertification, but high alkalinity of the traditional planting concrete severely limits its application (27). The hypothesis of

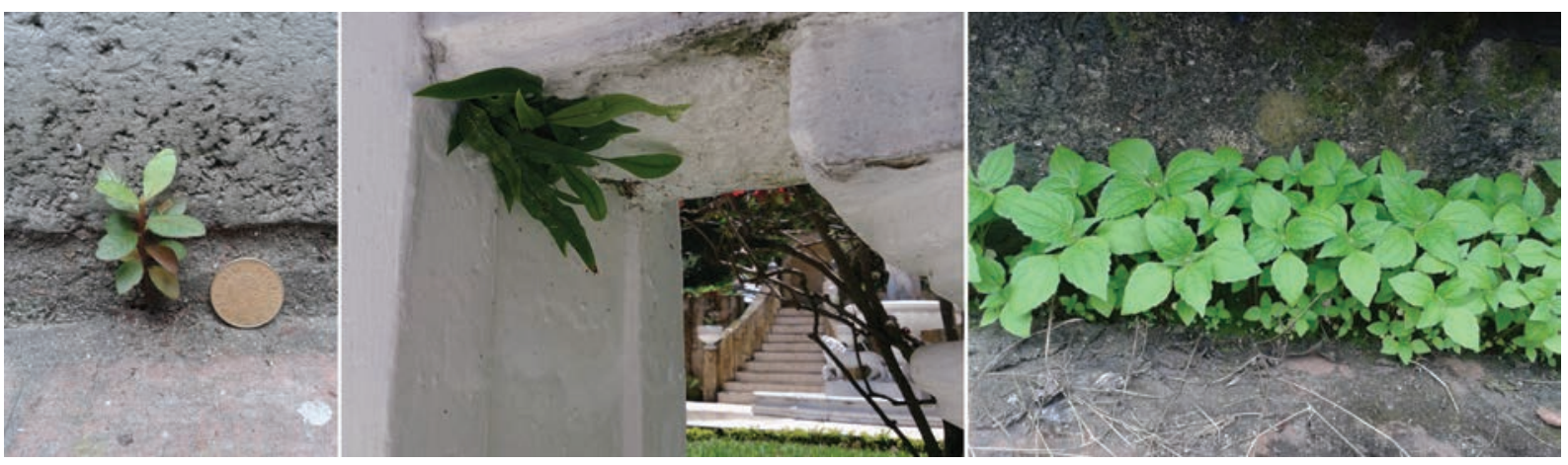

FIGURE 1. Unidentified plant species growing in concrete of urban structures (Photos: E. Mejia). 
this paper is that some microorganisms associated to plant roots grown in surface-deteriorated concrete of urban structures are capable of dissolving concrete and therefore release elements into solution that could be taken by plants. This may be possible because the urban structures have a chemical and mineralogical composition that resembles that composition of soil minerals that support plant life.

This work helps to understand the combined role of Aspergillus carbonarius and higher plants, established in urban structures, on the concrete dissolution. Thus, the aim of this study was to isolate and identify microorganisms from plant roots growing on the surface of deteriorated concrete structures that exhibited different pathologies, to test the capacity of selected microorganisms to dissolve concrete particles (under in vitro conditions), and to identify the mechanisms by which microorganisms and plants cause biodeterioration of those concrete structures.

\section{MATERIALS AND METHODS}

\subsection{Concrete}

The concrete sample used in this study was provided by the Laboratory of Concretes of the Universidad Nacional de Colombia at Medellin. The concrete was cut into samples of $5 \times 5 \times 0.4 \mathrm{~cm}$.

\subsection{Concrete characterization}

The concrete sample was examined by $\mathrm{X}$-Ray Fluorescence, using an Energy-Dispersive Spectrometer PANalytical, MinPal 2 with direct excitation in 2D, $9 \mathrm{~W}(30 \mathrm{KW}, 1 \mathrm{~mA})$ chrome irradiation tube, Si-PIN detector, 12-position sample changer, 100-240 V, 45-65 Hz. The mineralogical composition of the concrete was determined by XRD, using a PANalytical Reference X'Pert PRO MPD with $\mathrm{Cu}$ radiation of wavelength $\mathrm{K} \alpha 1=1.5406$ A. Power: $45 \mathrm{kV}$ and $40 \mathrm{~mA}$. scanning: step-size of $0.013^{\circ}$ at a speed of 59 s per step with continuous scanning.

\subsection{Isolation of cultivable bacteria and fungi}

Urban structures showing visible symptoms of deterioration were chosen in the city of Medellin, Colombia $\left(06^{\circ} 15^{\prime} \mathrm{N}, 75^{\circ} 35^{\prime} \mathrm{W}\right)$. Four concrete samples were collected from buildings with evidence of degradation (discoloration, cracking, and mass loss). Two of these samples were taken from structures that had herbaceous plants growing in concrete materials (soilless), and another two samples were taken from lichens growing directly on concrete. All the samples were scrapped with knife and forceps which were previously disinfected with ethanol $(90 \%)$.
Particles of concrete attached to plant roots or lichens, evidencing deterioration, were transferred directly $(0.1 \mathrm{~g})$ to Petri dishes or serial-diluted with saline solution $\left(0.01 \mathrm{M} \mathrm{CaCl}_{2}\right)$. The dilutions ranged from $10^{-1}$ to $10^{-3}$. Meanwhile, the plant roots were cut into $1 \mathrm{~cm}$ fragments, rinsed with saline solution, and then transferred directly to the culture medium (autoclaved PDA or nutrient agar) in Petri dishes. The culture medium contained either antibiotics (tetracycline $200 \mathrm{mg} / \mathrm{L}$, streptomycin sulphate $200 \mathrm{mg} / \mathrm{L}$ ) or fungicides (benomyl $100 \mathrm{mg} / \mathrm{L}$ ), which were used by duplicate to isolate fungi or bacteria, respectively. Petri dishes were incubated for four days at $26^{\circ} \mathrm{C}$.

The microbial isolates were morphologically identified and the number of colony forming units (CFU) was registered. After this, they were purified in separate Petri dishes, in the same culture medium, and multiplied over the course of eight days at $26^{\circ} \mathrm{C}$.

Then, all purified isolates were transferred with a sterile loop into Petri dishes containing a sterile nutrient medium (glucose $10 \mathrm{~g} / \mathrm{L}, \mathrm{NH}_{4} \mathrm{Cl} 1 \mathrm{~g} / \mathrm{L}$, bromothymol blue as $\mathrm{pH}$ indicator, agar-agar $15 \mathrm{~g} / \mathrm{L}$, and $70-200 \mu \mathrm{m}$ concrete particles $3.5 \mathrm{~g} / \mathrm{L}$ ), this was referred as the concrete medium. The $\mathrm{pH}$ indicator permitted the detection of microorganisms capable of decreasing $\mathrm{pH}$ (presumably by exuding organic acids). The medium was previously autoclaved for 15 minutes at $0.1 \mathrm{MPa}$. Autoclaved concrete particles were added to the surface of the agarized medium before its solidification. The Petri dishes were then incubated for four days at $26{ }^{\circ} \mathrm{C}$ and the microbial isolates that formed yellow halos (indicator of acid production) were selected, multiplied in the same medium, and suspended in sterile distilled water and conserved at $4{ }^{\circ} \mathrm{C}$ for further use.

\subsection{Fungal DNA extraction and PCR amplification}

The DNA extraction for the isolated acidityproducing fungus was made at the Corporación para Investigaciones Biológicas (CIB) at Medellin. This procedure allowed us to identify the fungus at the level of species using a molecular marker in its DNA, which is unique for each fungal species as explained by Schoch et al. (28). To this purpose, the ITS1-5.8rSADN-ITS2 del rDNA region was amplified using the primers ITS1 (5' TCCGTAGGTGAACCCTGCGG 3') and ITS4 (5' TCCTCCGCTTATTGATATGC 3') (28). The amplification by PCR was made in a thermocycler (System 9700 GeneAmp®), the denaturation time was $2 \mathrm{~min}$ at $95{ }^{\circ} \mathrm{C}, 30$ cycles of $95{ }^{\circ} \mathrm{C}$, for $45 \mathrm{~s}, 72{ }^{\circ} \mathrm{C}$ for $1 \mathrm{~min}$ and a final extension at $72{ }^{\circ} \mathrm{C}$ for $5 \mathrm{~min}$. The amplification products were separated by electrophoresis in 1\% agarose gel (SIGMA $\left.{ }^{\circledR}\right)$, stained with ethidium 
bromide $(0.2 \mu \mathrm{g} / \mathrm{ml})$, visualized in a transilluminator (BioDoc-IT image system, UVP ${ }^{\circledR}$ and sequenced by the company MACROGEN, Seoul, Korea). Finally, the molecular identification was performed comparing the sequences obtained by Bio-Rad software and NCBI (National Center for Biotechnology) database.

\subsection{In vitro dissolution of concrete particles}

Two suspensions of $5 \mathrm{~mL}$ each one containing bacterium, and fungus respectively were aseptically transferred into $250 \mathrm{~mL}$ Erlenmeyer flasks containing $100 \mathrm{~mL}$ of autoclaved concrete medium with neither agar nor $\mathrm{pH}$ indicator. The flasks were shaken in a reciprocal shaker at $110 \mathrm{rpm}$, at $25^{\circ} \mathrm{C}$ for seven days. After the incubation period, the medium $\mathrm{pH}$ was measured directly with a $\mathrm{pH}$ electrode (WTW electrode Sentix 81), and the concentrations of soluble silicon in the medium were measured using the blue-molybdate method at $860 \mathrm{~nm}$ in a spectrophotometer (Genesys 20, Thermo Spectronic) before centrifugation at $4000 \mathrm{rpm}(1520 \mathrm{xg})$ for 10 minutes (Jouan MR 1812 centrifuge), and filtration through a Whatman No. 42 filter paper. Soluble calcium was determined by atomic absorption in an AA Perkin Elmer 2380 spectrometer.

\subsection{Data Analysis}

The experimental design was completely randomized; three treatments, uninoculated control, fungal inoculation, and bacterial inoculation were tested, and for each treatment four replicates were run. Data were subjected to ANOVA and Duncan tests both at a significance level of $(P) \leq 0.05$. This was conducted using the statistical software Statgraphics Centurion.

\section{RESULTS}

\subsection{Chemical Characterization with X-Ray fluorescence}

The concrete sample was composed mostly of silicon, followed by calcium, iron, magnesium, phosphorous, and potassium, among others (Table 1). Other elements were found in smaller quantities, including Ti, Na, Mn, Cr, and $\mathrm{S}$.

XRD was used to confirm the mineral phases associated with the concrete. The mineral phases detected were quartz $\left(\mathrm{SiO}_{2}\right)$, calcite $\left(\mathrm{CaCO}_{3}\right)$, albite and actinolite $\left(\mathrm{Ca}_{2}\left(\mathrm{Mg}, \mathrm{Fe}^{2+}\right) 5 \mathrm{Si}_{8} \mathrm{O}_{22}(\mathrm{OH})_{2}\right)$ (Figure 2). It is important to note that the mineralogical phases present in cement paste can be masked by the previously mentioned minerals, which may be the components of concrete aggregates.
TABLE 1. Chemical composition of concrete. X-ray fluorescence

\begin{tabular}{lccc}
\hline Oxides & $\%$ & Oxides & $\%$ \\
\hline $\mathrm{SiO}_{2}$ & 41.0 & $\mathrm{MgO}$ & 2.38 \\
$\mathrm{CaO}$ & 31.0 & $\mathrm{Na}_{2} \mathrm{O}$ & $<0.010$ \\
$\mathrm{Al}_{2} \mathrm{O}_{3}$ & 9.58 & $\mathrm{~K}_{2} \mathrm{O}$ & 0.99 \\
$\mathrm{Fe}_{2} \mathrm{O}_{3}$ & 3.68 & $\mathrm{MnO}$ & 0.14 \\
$\mathrm{P}_{2} \mathrm{O}_{5}$ & 2.36 & $\mathrm{Cr}_{2} \mathrm{O}_{3}$ & 0.06 \\
$\mathrm{TiO}_{2}$ & 0.67 & $\mathrm{SO}_{3}$ & 0.93 \\
& (Loss on ignition 6.92) \\
\hline
\end{tabular}

\subsection{Isolation of cultivable bacteria and fungi from plant roots}

Some urban structures in Medellin, particularly old buildings and abandoned sites, exhibited plant and microbial growth, which was associated with degradation of these surfaces, including concrete mass loss, darkening, and softening (Figures 3 and 4). Different kinds of plants were observed, many of them belonging to the Asteraceae family, such as Galingosa ciliata, and the leguminosae family such as Leucaena leucocephala (Figure 3).

The microorganisms (fungi and bacteria) that were detected in the urban structures, grew upon plant roots, moss, and in degraded concrete (Table 2). The CFU populations of bacteria and fungi were detected in the rhizosphere, moss, and in degraded concrete. It is worth mentioning that different bacterial and fungal morphotypes were isolated. In all samples the most frequent microorganisms were six fungi and four bacteria (Table 2).

Finally, eight microbial isolates from the samples were able to grow in solid media; however, evidence of acid production (seen in halo formation around colonies or moderate color change) was detected in only one fungal isolate (Figure 4). This fungus was found inhabiting the samples 1, 2 , and 5 and had white mycelium and black spores (Figure 5). Then, DNA procedures and morphological features allowed the identification of this fungus as Aspergillus carbonarius. The fungus has $100 \%$ ITS sequence similarity to the strain AC06 (EU926157) from the National Center for Biotechnology Information (NCBI) database (www.ncbi.nlm.nih.gov)

The SEM images showed the A. carbonarius structure, and it was characterized for having a tabular hypha with a "head" (vesicle, metulae, phialides, and conidiofore) located at the far right; the head evidenced the presence of spores (Figure 6). The molecular identification allowed concluding that de fungus was $A$. carbonarius.

In vitro tests showed that concrete medium inoculated with a fungal isolate (A. carbonarius) 


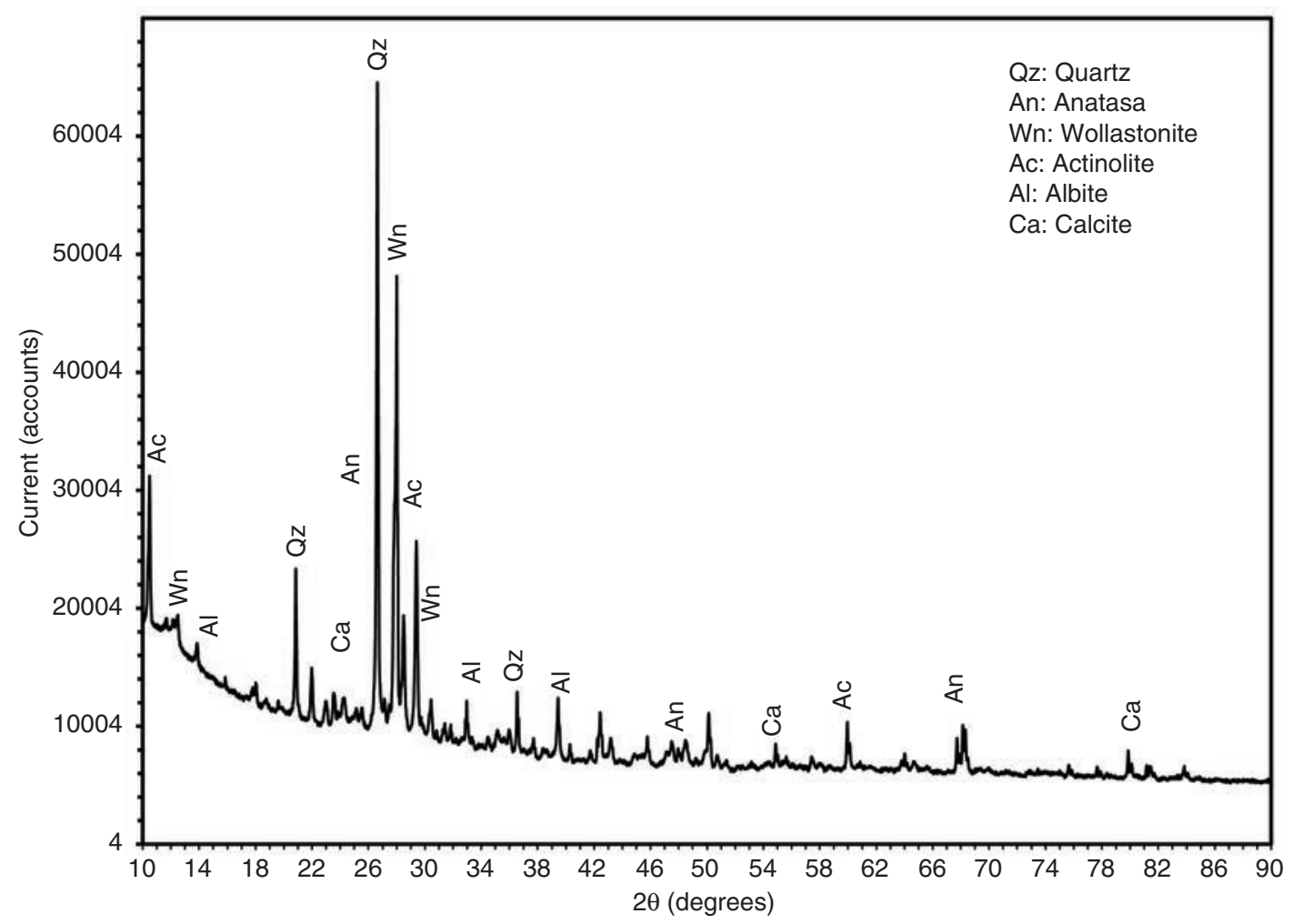

FIGURE 2. X-ray diffraction of fine concrete waste. Where $\mathrm{Qz}$ is quartz, An is anatase, Wn is wollastonite, Ac is actinolita, $\mathrm{Al}$ is albite and $\mathrm{Ca}$ is calcite. (Mejia et al. (29) source).
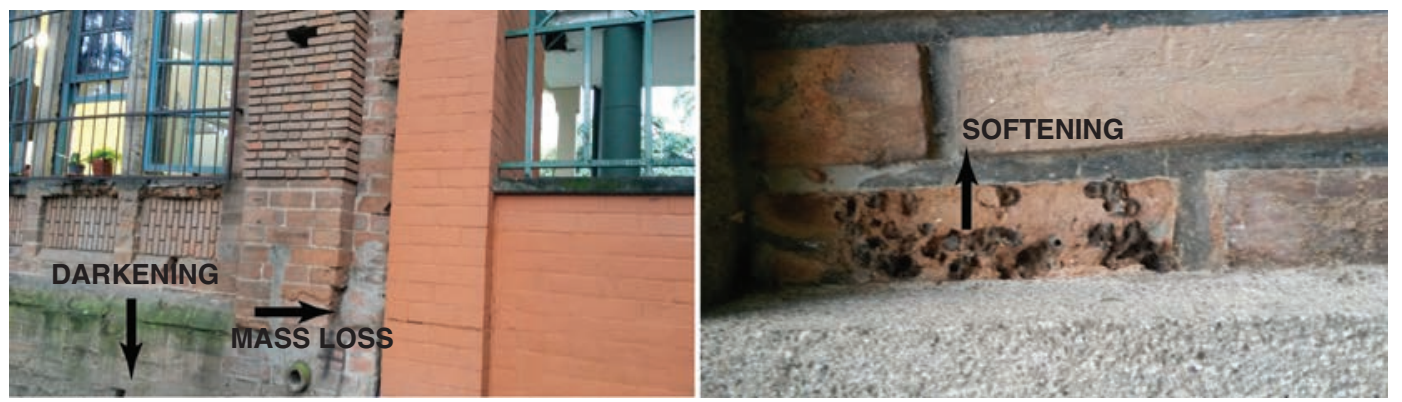

FIGURE 3. Stone structure degradation caused by external agents. The structures displayed mass loss and darkening. Universidad Nacional de Colombia at Medellin. Left: sample 3 and 4; Right: sample 5. (see table 2) (Photos: E. Mejia).

had a significantly lower $\mathrm{pH} 4.0$ than the uninoculated control pH 8.0 (Figure 7). For instance, at the end of the incubation period ( $7 \mathrm{~d})$, the control had a calcium concentration of $172.3 \mathrm{mg} / \mathrm{L}$ and a soluble silicon concentration of $10.3 \mathrm{mg} / \mathrm{L}$, while the inoculated medium had significantly higher values (525.0 and $50.1 \mathrm{mg} / \mathrm{L}$, respectively) (Figures 8 and 9). This represents a calcium concentration three times higher, and a silicon concentration five times higher than in the uninoculated control (Figures 8 and 9).

\section{DISCUSSION}

The XRF showed elements that could be used as nutrients for microorganisms and plants. However, since these elements form part of minerals with low solubility, they should be bioavailable as nutrients for microorganisms and plants for example via bioacidulation, which enables their release (30). Their dissolution reactions in an acidic environment are specified in equations 1-3 for portlandite, calcite and C-S-H. 
TABLE 2. Colony forming units (CFU) of fungi and bacteria isolated from plant roots, moss, and degraded concrete. (ND: not detected).

\begin{tabular}{|c|c|c|c|}
\hline Sample & Source & $\begin{array}{l}\text { Fungi (CFU per g) } \\
\end{array}$ & Bacteria (CFU) \\
\hline 1 & Plant root & $\begin{array}{l}2 \times 10^{4}: \text { Description: white mycelium with black spores } \\
6 \times 10^{6}: \text { yellow mycelium with black spores }\end{array}$ & ND \\
\hline 2 & Plant root & $\begin{array}{l}1 \times 10^{4} \text { Description: white mycelium with black spores } \\
4 \times 10^{3} \text { Description: yellow mycelium with black spores } \\
7 \times 10^{3} \text { Description: White mycelium } \\
4 \times 10^{4} \text { Description: Orange mycelium } \\
1 \times 10^{2} \text { Description: Blue mycelium } \\
1 \times 10^{2} \text { Description: Dark green mycelium }\end{array}$ & ND \\
\hline 3 & Moss & 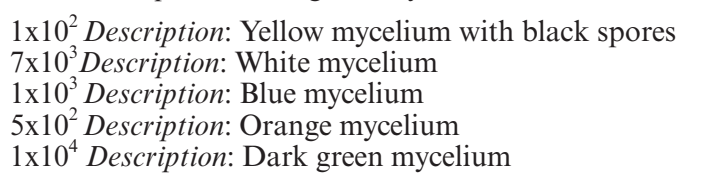 & $\begin{array}{l}1 \times 10^{2} \text { Description: pinkish } \\
8 \times 10^{3} \text { Description: Orange }\end{array}$ \\
\hline 4 & Moss & $\begin{array}{l}4 \times 10^{6} \text { Description: White mycelium with black spores } \\
6 \times 10^{6} \text { Description: Yellow mycelium with black spores }\end{array}$ & $\begin{array}{l}\text { 8.3 } \times 10^{6} \text { Description: } \text { White } \\
6.8 \times 10^{6} \text { Description: Yellow } \\
7.2 \times 10^{6} \text { Description: Pinkish } \\
4.7 \times 10^{6} \text { Description: Corn }\end{array}$ \\
\hline 5 & Concrete & $\begin{array}{l}\text { 3.8 } 810^{6} \text { Description: White mycelium with black spores } \\
\text { 4.9 } 910^{6} \text { Description: Yellow mycelium with black spores } \\
7.5 \times 10^{6} \text { Description: White mycelium }\end{array}$ & 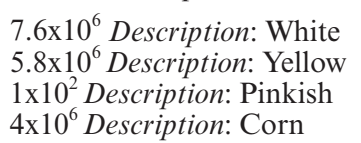 \\
\hline 6 & Concrete & $2.8 \times 10^{6}$ Description: White mycelium & $\begin{array}{l}\text { 6.2 } \times 10^{6} \text { Description: } \text { White } \\
5.8 \times 10^{6} \text { Description: Yellow } \\
6.3 \times 10^{6} \text { Description: Pinkish }\end{array}$ \\
\hline 7 & Concrete & 4.9x $10^{6}$ Description: White mycelium & Description: $1.0 \times 10^{4}$ White \\
\hline 8 & Concrete & $2 \times 10^{3}$ Description: White mycelium & $\begin{array}{l}\text { 8.2 } 2 \times 10^{6} \text { Description: } \text { white } \\
6.4 \times 10^{6} \text { Description: Yellow } \\
6.9 \times 10^{6} \text { Description: Corn }\end{array}$ \\
\hline
\end{tabular}
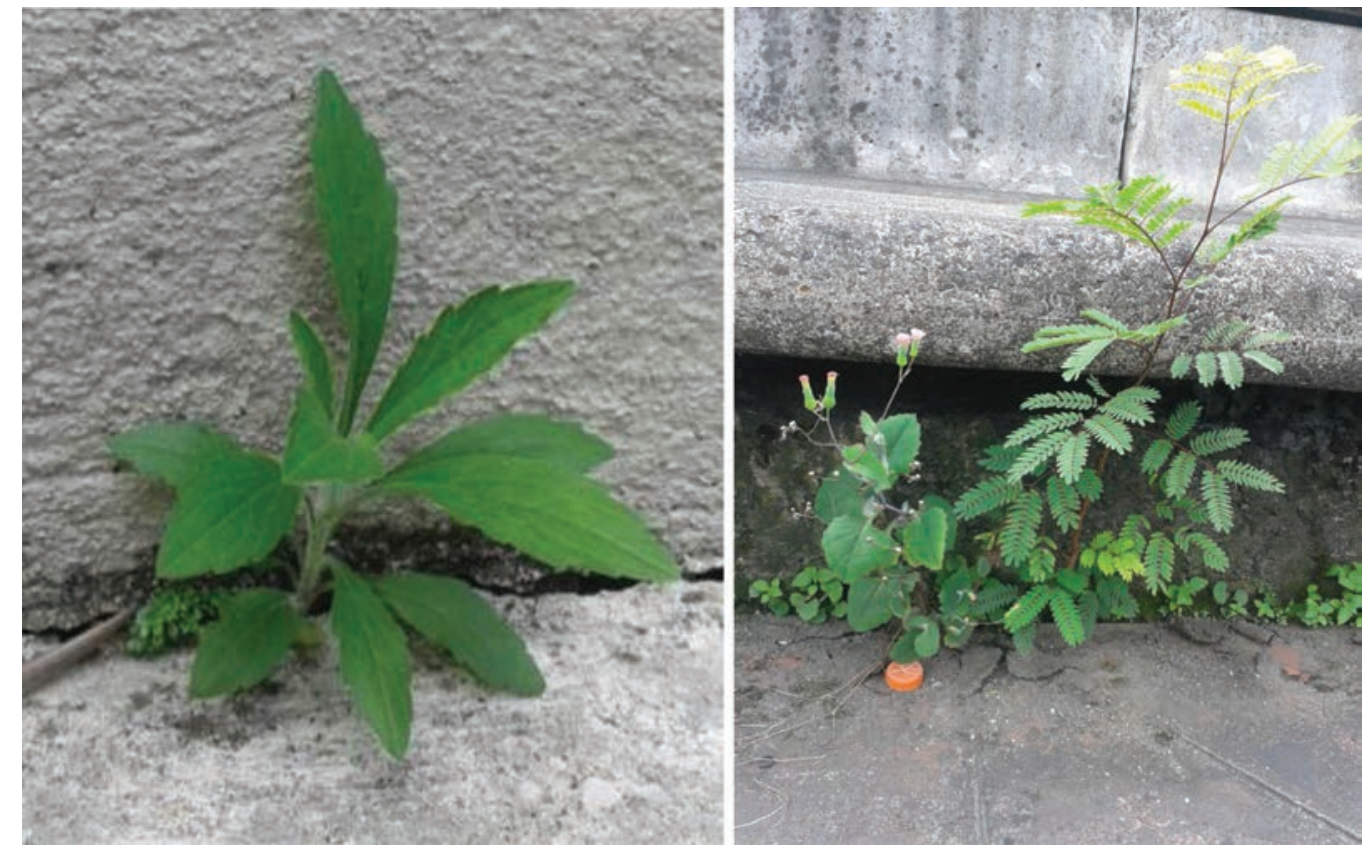

Figure 4. Left: A Galingosa ciliata (Asteracea) observed in an urban structure in the city of Bello, Colombia. Right: B Leucaena leucocephala (Mimosaseae) growing on the Universidad Nacional de Colombia at Medellin campus. Left: sample 1 and 6 of table 2. Right: sample 2, 7 and 8 of table 2 (Photos: E. Mejia). 

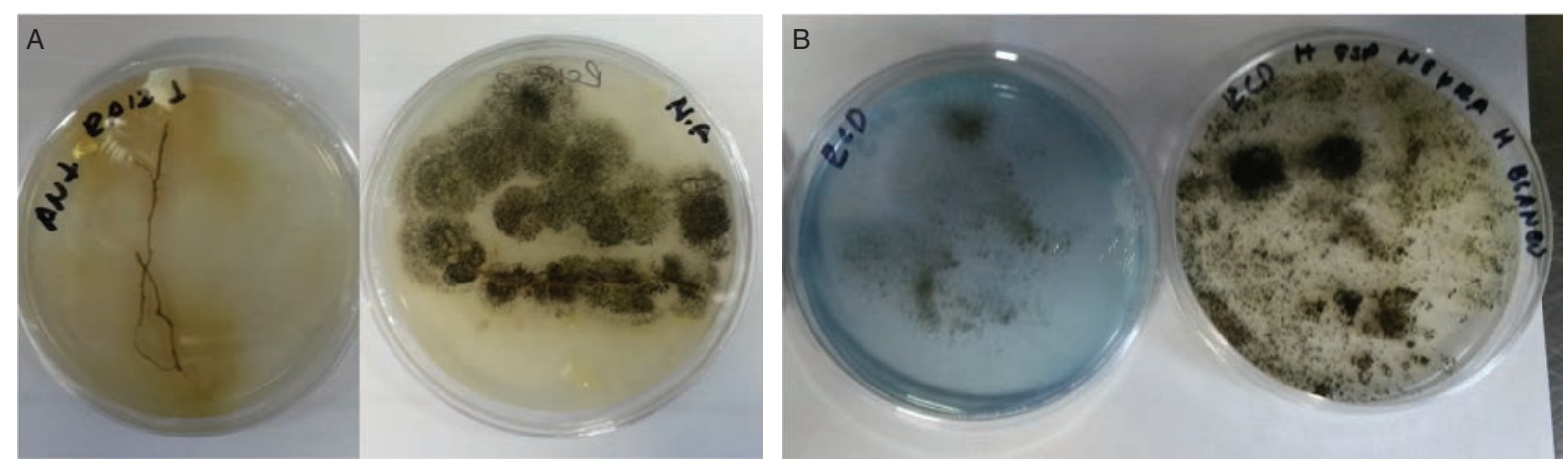

FIGURE 5. A: Culture medium exhibiting fungal growth from root samples of plants growing in an urban structure, at $48 \mathrm{~h}$ (upper left) and $72 \mathrm{~h}$ of growth (upper right). B: Culture medium without inoculation (lower left) and with inoculation (lower right); note the color change on the right as a result of acid production by a fungal isolate. The blue color in the medium indicated a basic medium and its changes indicated the acidification.
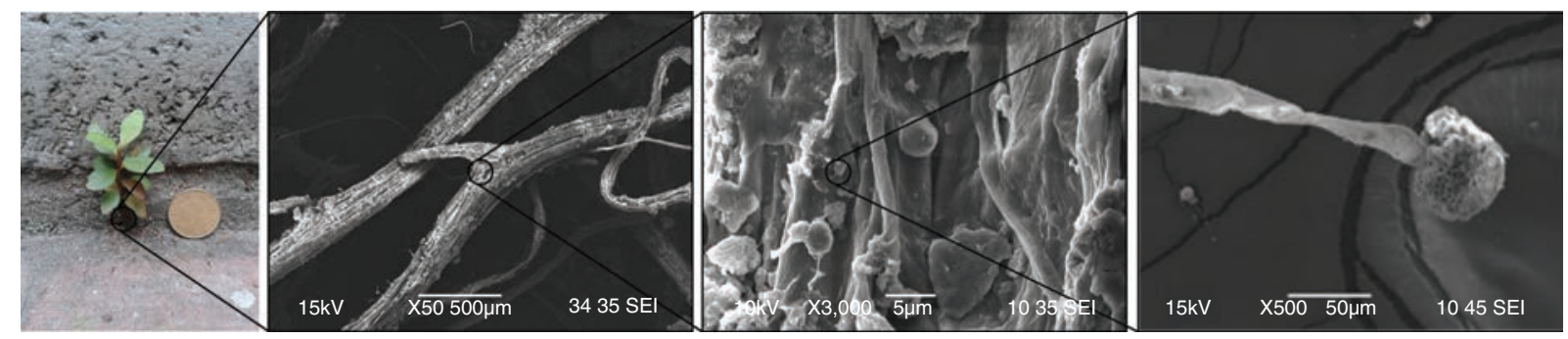

FIGURE 6. A. carbonarius growth from root samples of plants growing in an urban structure and roots of Asteraceae plant showed by SEM.

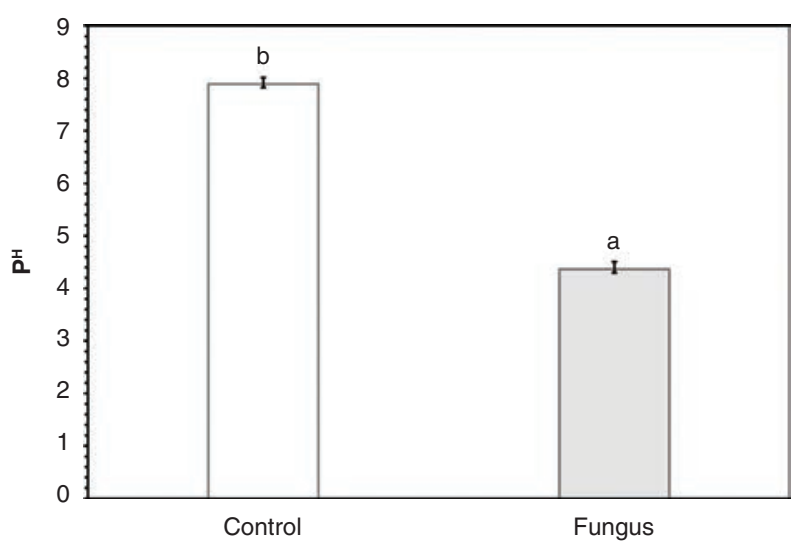

FIGURE 7. Changes in $\mathrm{pH}$ of the medium either uninoculated or inoculated with the fungus. Each bar represents the average of four repetitions. Standard deviations are represented at the top of each bar. Different lowercase letters indicate significant differences between treatments effect according to the Duncan test $(\mathrm{p} \leq 0.05)$.

$$
\begin{gathered}
\mathrm{CaCO}_{3}+2 \mathrm{H}^{+} \rightarrow \mathrm{Ca}^{2+}+\mathrm{CO}_{2}+\mathrm{H}_{2} \mathrm{O} \\
\mathrm{Ca}(\mathrm{OH})_{2}+2 \mathrm{H}^{+} \rightarrow \mathrm{Ca}^{2+}+2 \mathrm{H}_{2} \mathrm{O} \\
\mathrm{C}-\mathrm{S}-\mathrm{H}+\mathrm{H}^{+} \rightarrow \mathrm{Ca}^{2+}+\mathrm{SiO}_{2}+\mathrm{H}_{2} \mathrm{O}
\end{gathered}
$$

The bioacidulation process consists of the following steps: (i) the organic acid produced by $A$.

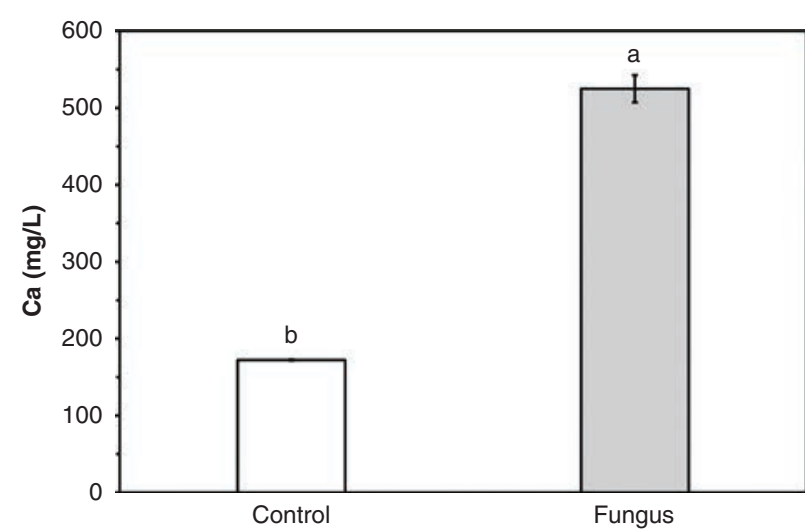

FiguRE 8. Calcium concentration ( $\mathrm{mg} / \mathrm{L})$ in the medium either uninoculated or inoculated with the fungus. Each column represents the average of four repetitions. The bars indicate standard deviation. Columns with different lowercase letters indicate significant differences between treatments effect according to the Duncan test $(\mathrm{p} \leq 0.05)$.

carbonarius is hydrolyzed, releasing protons; (ii) these protons react with the portlandite and carbonates, because it had a greater solubility and leaving $\mathrm{Ca}$ in solution; (iii) the protons react with $\mathrm{C}-\mathrm{S}-\mathrm{H}$ leaving $\mathrm{Ca}$ and $\mathrm{Si}$ in solution. The dissolution of portlandite and carbonates in acid medium has been reported by Vaniale et al. (5). The released 


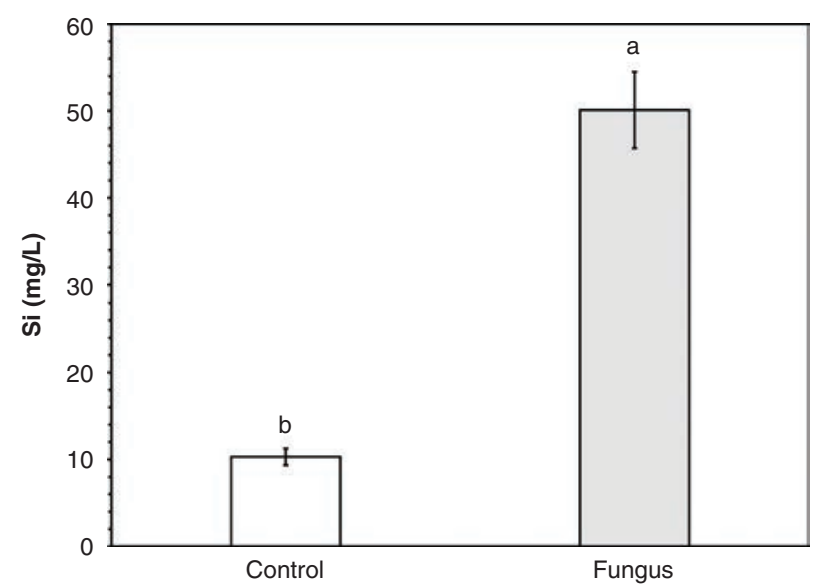

FIGURE 9. Silicon concentration $(\mathrm{mg} / \mathrm{L})$ in the medium either uninoculated or inoculated with the fungus. Each column represents the average of four repetitions. The bars indicate standard deviation. Columns with different lowercase letters indicate significant differences between treatments effect according to the Duncan test $(P \leq 0.05)$.

silicon probably comes from the C-S-H because of this phase is more unstable compared to the rocks used as aggregates in our region, which are composed of igneous and metamorphic rocks such as dunite, gabbro, diorite, granodiorite, amphibolite, gneiss, among others (31). In this way the C-S-H dissolution endanger the mechanical properties of concrete, because the C-S-H is the main responsible for the cementing properties of the materials made from Portland cement. In general, it could be said that organic acid reacts with portlandite, calcium carbonates, and silicates, which contain highly insoluble compounds, to produce highly soluble salts and their respective free species in solution (Equation 4).

$$
\begin{gathered}
\text { Organic acid }+(\text { Carbonates, } \mathrm{CH}, \mathrm{C}-\mathrm{S}-\mathrm{H}) \\
\text { Very insoluble } \rightarrow \text { Calcium salts very } \\
\text { soluble } \rightarrow \mathrm{Ca}^{2+}+\mathrm{H}_{4} \mathrm{SiO}_{4} \text { (in solution) }
\end{gathered}
$$

On the other hand, the isolated bacteria and fungi were similar to those commonly found in soils (27). These microorganisms could cause concrete degradation by producing organic acid and mineral dissolution, thus releasing nutrients $(16,26)$. Moreover, plants growing in urban structures (soilless) seem to be capable of adapting to adverse conditions.

The Aspergillus carbonarius has the ability to reduce $\mathrm{pH}$ of culture medium and concrete. This is quite significant because fungi from this genus are very active in organic acid production (e.g., citric acid, oxalic acid, malic acid), which is responsible of major bioweathering and biodeterioration (1). This result is relevant because previous investigations showed that organic acid could dissolved concrete and release the calcium (27), and in this way concrete structure can be degraded. It is possible that this soluble calcium came from the dissolution of calcium carbonate and hydrated products of cementitious systems (24). Moreover, the increase in silicon concentration in the medium is evidence of $\mathrm{C}-\mathrm{S}-\mathrm{H}$ dissolution. It can be inferred that despite the high stability of concrete under outdoor conditions, it may be deteriorated by the action of microorganisms (dissolution due to acid production), and hyphae (physical damage due to their growth); this deterioration may presumably be more aggressive under tropical conditions. The changes on the physical, chemical, and mineralogical properties of concrete are comparable with the degradation of urban structures and sculptures reported by Collingnon et al. (33) and Sun et al. (20).

Lian et al. (34) also reported that concrete deterioration caused by organic acids produced by fungi led to the instability and dissolution of minerals such as carbonates, portlandite, among others. Studies conducted by other authors found that one of the predominant factors in the dissolution of rocks, minerals, and urban structures are caused by microbial activity. Wei et al. (18) found that fungi are the most harmful organism to the biodeterioration of concrete and stone due to this capacity to: (i) settle on the rocks and concrete surface, (ii) attach firmly to the surface, and (iii) penetrate deeper into the rock or concrete.

It is important to note that, although researchers have reported urban structure biodeterioration caused by Aspergillus niger (16), the biodeterioration caused by $A$. carbonarius has not been reported by other researchers. This fungus lowers the $\mathrm{pH}$ of the generated organic acids and favors the dissolution of the concrete. The results show that $A$. carbonarius accelerates the dissolution of the concrete by exuding organic acids. Moreover, $A$. carbonarius developed a symbiotic action with the plant's biosphere and concrete allowing: (i) the decrease the $\mathrm{pH}$ of the medium, and (ii) the increase of the $\mathrm{Ca}$ and $\mathrm{Si}$ in the solution to feed the plant (Figure 10). In exchange, the fungus obtained energy via plant photosynthesis. This synergistic effect generated by concrete, plant, and microorganisms is complex and the systems involved in it are very diverse. Therefore, the concrete surface (artificial rock) is colonized by $A$. carbonarius which reduces the $\mathrm{pH}$ on the surface and facilitates the availability of nutrients such us $\mathrm{Ca}$ and $\mathrm{Si}$. The plant roots grow and release carbonaceous compounds to its surrounding substrate, and these compounds are used by the microorganisms that inhabit these mineral matrices. In this way, this interaction affects the stability of the concrete structure, because these microorganism (e.g., $A$. carbonarius) produce acidity that leads to the dissolution of some minerals contained in the concrete. The nutrients left in the solution permit the deposition of organic material (plant debris) and allow plant establishment. That is, the weathering 


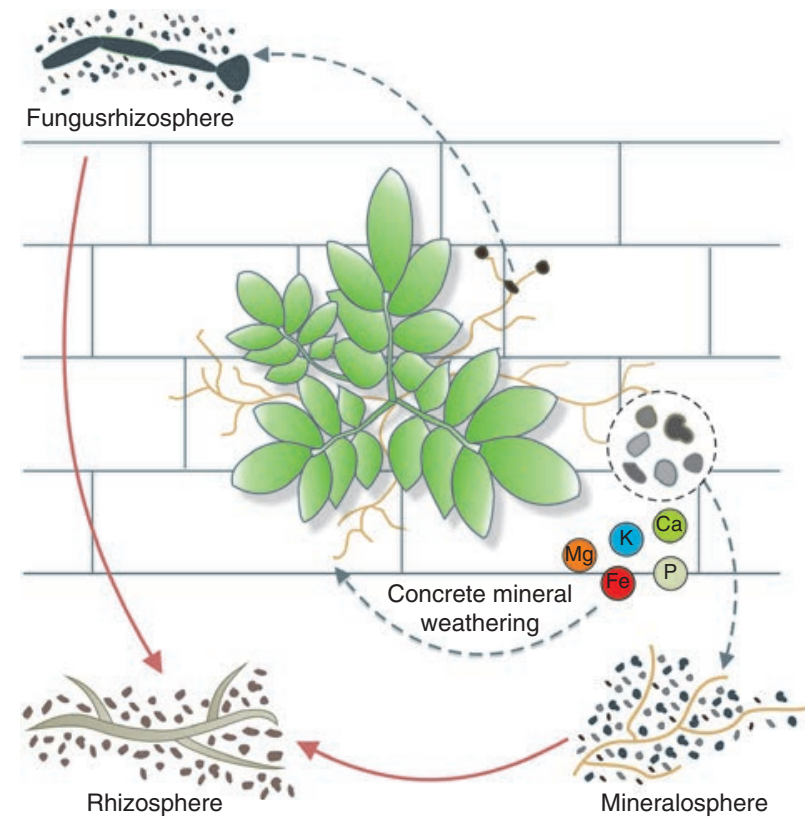

FIGURE 10. Draw of a higher plant growing on a concrete material. The plant roots exudate carbonaceous compounds that promote growth of microbial population in the mineral matrix; this is an equivalent concept to the mineralsphere proposed by Uroz et al. (34) in plant-soil systems.

of concrete by means of organic acids which in turn are produced by fungus allows the formation of a new phase called "mineralosphere" as named by Uroz et al. (35), (36). This is a nutrient source for microorganisms and plants. It is important to note that the establishment and development of plants in urban structures induces microcracks propagation in the concrete, thus facilitating the entry of water and generating favorable conditions for biodeterioration.

During the formation of soil, from rocks and minerals, the continuous weathering that occurs in the mineralosphere, caused by the plant-microorganism interaction, allows the formation of new "soil" and therefore the soil rhizosphere. In the proposed model showed in Figure 10 the role of the fungus $A$. carbonarius was to provide soluble nutrients ( $\mathrm{Ca}, \mathrm{P}, \mathrm{Si}$, etc.), and in this way it favors plant development and establishment in urban structures.

The result showed that plants that are established in urban structures are commonly found were Asteraceae family is present. This kind of plants seems to easily adapt to adverse conditions due to the synergic association with microorganism (Figure 10).

Additional to the understanding of who and how produces concrete biodeterioration, which was the fundamental objective of this investigation, opens possibilities for the application of this knowledge. It is worth noting that the minerals found in concrete are commonly found in soils as well, and presumably, soil microorganisms might dissolve them. This is possible because the isolated microorganisms from degraded concrete systems are similar to those frequently found in soils e.g., A. carbonarius. For this reason, presumably these kinds of construction and demolition waste may be used in restoration processes for soils degraded by anthropic activities, and in this way it may favor the establishment of plants and their associated microbes; the recovery/restauration of landscapes by using these demolition waste and the microorganisms may help offering recreational opportunities by the usage of restored soil and/or productivity in terms of agriculture $(19,36)$, but further studies should be focused on determining the use of concrete waste as a source of nutrients in degraded soils.

\section{CONCLUSIONS}

From all the isolated microorganisms in urban structures, only one was capable of acidification, and this was identified as Aspergillus carbonarius which can colonize urban structures, and induce deterioration by producing organic acid. The dissolution of concrete promotes the release of key elements, such as calcium and silicon, for the establishment of plants; these elements are essential components of concrete and their loss affect the durability and strength of concrete structures.

The plants found in urban structures were those of the Asteraceae family, which have low nutritional requirements and their rhizosphere is associated to microorganisms like Aspergillus carbonarius.

The interaction among urban structures, colonizers microorganisms, and plants accelerates the biodeterioration processes generating physical, chemical, and biological damages of the urban structures. The acidifying activity of $A$. carbonarius allows the decrease of $\mathrm{pH}$ of the medium and the increase of $\mathrm{Ca}$ and $\mathrm{Si}$ in solution to feed plant.

This work helps to understand the combined role of Aspergillus carbonarius and higher plants established in urban structures on the concrete dissolution. The bioacidulation carried out by the fungus promotes the dissolution of minerals and the consequent release of nutrients such as calcium and silicon; in this way, it favores the nutrition of the plants established in these structures. It is important to note that the plants provide carbonaceous compounds to the fungus (via root exudates) from which the fungus feeds, thus establishing a mutualistic relationship between them (plant-fungus). The results reported here can be useful to improve the maintenance programs of urban structures. In addition, they are relevant for bioprospecting microorganisms to be used in soil restoration programs in which low solubility minerals can be applied, which should be investigated. 


\section{ACKNOWLEDGEMENTS}

The authors thank the Universidad de San Buenaventura at Medellin for funding the project No. 951-14.01.50, the Universidad Nacional de Colombia at Medellín, and COLCIENCIAS National Doctoral Program No. 567.

\section{REFERENCES}

1. Cwalina, B. (2008) Biodeterioration of Concrete. J. Archit. Civ. Eng. Environ. 4, 133-140. http://doi.org/10.1533/97817 82421252.3.281.

2. Larreur-Cayol, S.; Bertron, A.; Escadeillas, G. (2011) Degradation of cement-based materials by various organic acids in agro-industrial waste-waters. Cem. Concr. Res. 41[8], 882-892, 2011. https://doi.org/10.1016/j. cemconres.2011.04.007.

3. Warscheid, T.; Braams, J. (2000) Biodeterioration of stone: A review," Int. Biodeterior. Biodegrad. 46[4], 343-368. https://doi.org/10.1016/S0964-8305(00)00109-8.

4. Okabe, S.; Odagiri, M.; Ito, T.; Satoh, H. (2007) Succession of sulfur-oxidizing bacteria in the microbial community on corroding concrete in sewer systems. Appl. Environ. Microbiol. 73[3], 971-980. https://doi.org/10.1128/AEM. 02054-06.

5. Veniale, F.; Setti, M.; Lodola, S. (2008) Diagnóstico del deterioro de la piedra en el patrimonio construido. Datos y perspectivas. Mater. Construcción. 58, 11-32.

6. Westall, F.; Cornel, E.J:, Southam, G.; Grassineau, N., Colas, M., Cockcell, C., Lammer, H. (2006) Implications of a 3.472-3.333 Gyr-old subaerial microbial mat from the Barberton greenstone belt, South Africa for the UV environmental conditions on the early Earth. Philos. Trans. R. Soc. B Biol. Sci. 361[1474], 1857-1876. https://doi.org/10.1098/rstb.2006.1896.

7. Baskar, S.; Baskar, R.; Mauclaire, L.; McKenzie, J. A. (2006) Microbially induced calcite precipitation in culture experiments: Possible origin for stalactites in Sahastradhara caves, Dehradun, India. Curr. Sci., 90[1], 58-64.

8. Epure, L.; Meleg, I. N.; Munteanu, C.-M.; Roban, R. D.; Moldovan, O. T. (2014) Bacterial and Fungal Diversity of Quaternary Cave Sediment Deposits. Geomicrobiol. J. 31[2] 116-127. https://doi.org/10.1080/01490451.2013. 815292

9. Papida, S.; Murphy, W.; May, E. (2000) Enhancement of physical weathering of building stones by microbial populations. Int. Biodeterior. Biodegrad. 46[4], 305-317. https:// doi.org/10.1016/S0964-8305(00)00102-5.

10. Windt, L. de; Bertron, A.; Larreur-Cayol, S.; Escadeillas, G. (2015) Interactions between hydrated cement paste and organic acids: Thermodynamic data and speciation modeling. Cem. Concr. Res. 69, 25-36. https://doi. org/10.1016/j.cemconres.2014.12.001

11. Kip, N.; Veen, J. A. van (2015) The dual role of microbes in corrosion. ISME J. 9[3], 542-551. https://doi.org/10.1038/ ismej.2014.169

12. Gu, J. D.; Ford, T. E.; Berke, N. S.; Mitchell, R. (1998) Biodeterioration of concrete by the fungus Fusarium. Int. Biodeterior. Biodegrad. 41[2], 101-109. https://doi. org/10.1016/S0964-8305(98)00034-1

13. Giannantonio, D. J.; Kurth, J. C.; Kurtis, K. E.; Sobecky, P. A. (2009) Effects of concrete properties and nutrients on fungal colonization and fouling. Int. Biodeterior. Biodegrad. 63[3], 252-259. https://doi.org/10.1016/j.ibiod. 2008.10.002

14. Noeiaghaei, T.; Mukherjee, A.; Dhami, N.; Chae, S. R. (2017) Biogenic deterioration of concrete and its mitigation technologies. Constr. Build. Mater. 149, 575-586. https://doi.org/10.1016/j.conbuildmat.2017.05.144

15. Wei, S.; Sanchez, M.; Trejo, D.; Gillis, C. (2010) Microbial mediated deterioration of reinforced concrete structures.
Int. Biodeterior. Biodegrad. 64[8], 748-754. https://doi. org/10.1016/j.ibiod.2010.09.001

16. Shi, C. (2017) A review on concrete surface treatment Part I : Types and mechanisms. Constr. Build. Mater. 132[1], 578590. https://doi.org/10.1016/j.conbuildmat.2016.12.025

17. Zhang, J. L.; Wu, R.S; Li, M.Y; Zhong, J.Y; Deng, X.; Liu, B.; Han, X.N.; Xing, F. (2016). Screening of bacteria for self-healing of concrete cracks and optimization of the microbial calcium precipitation process. 100[15], 66616670. https://doi.org/10.1007/s00253-016-7382-2

18. Wei, S.; Jiang, Z.; Liu, H.; Zhou, D.; Sanchez-Silva, M. (2013) Microbiologically induced deterioration of concrete - A review. Brazilian J. Microbiol. 44[4], 1001-1007. https:// doi.org/10.1590/S1517-83822014005000006

19. Rajakaruna, P. S.; Wilber, G. G. (2010). Microbial deterioration of concrete infrastructure. MSc Thesis, Oklahoma State University, Stillwater, Oklahoma.

20. Sun, X.; Jiang, G.; Bond, P. L.; Keller, J.; Yuan, Z. (2015) A novel and simple treatment for control of sulfide induced sewer concrete corrosion using free nitrous acid. Water Res. 70, 279-287. https://doi.org/10.1016/j.watres.2014.12.020

21. Bertron, A. (2014) Understanding interactions between cementitious materials and microorganisms: a key to sustainable and safe concrete structures in various contexts. Mater. Struct. 47[11], 1787-1806. https://doi.org/10.1617/ s11527-014-0433-1

22. Rodrigues, F.; Carvalho, M. T.; Evangelista, L.; De Brito, J. (2013) Physical-chemical and mineralogical characterization of fine aggregates from construction and demolition waste recycling plants. J. Clean. Prod. 52, 438-445. https://doi. org/10.1016/j.jclepro.2013.02.023

23. Mejía, E.; Navarro, P.; Vargas, C.; Tobón, J. I.; Osorio, W. (2016) Characterization of construction and demolition waste in order to obtain $\mathrm{Ca}$ and $\mathrm{Si}$ using a citric acid treatment Caracterización de un residuo de construcción y demolición para la obtención de Ca y Si mediante tratamiento con ácido cítrico. DYNA. 83, 94-101. https://doi. org/10.15446/dyna.v83n199.56394

24. Angulo, S. C.; Ulsen, C.; John, V. M.; Kahn, H.; Cincotto, M. A. (2009) Chemical-mineralogical characterization of C\&D waste recycled aggregates from Sao Paulo, Brazil. Waste Manag. 29[2], 721-730. http://doi.org/10.1016/j. wasman.2008.07.009

25. Limbachiya, M. C.; Marrocchino, E.; Koulouris, A. (2007) Chemical-mineralogical characterisation of coarse recycled concrete aggregate. Waste Manag. 27[2], 201-208. https://doi.org/10.1016/j.buildenv.2007.01.008

26. Sanchez-Silva, M.; Rosowsky, D. V. (2008) Biodeterioration of Construction Materials: State of the Art and Future Challenges. J. Mater. Civ. Eng. 20[5] 352-365. https://doi. org/10.1061/(ASCE)0899-1561(2008)20:5(352)

27. Gong, C.; Zhou, X.; Ji, L.; Dai, W.; Lu, L.; Cheng, X. (2018) Effects of limestone powders on pore structure and physiological characteristics of planting concrete with sulfoaluminate cement. 162[20], 314-320. https://doi. org/10.1016/j.conbuildmat.2017.10.012

28. Schoch, C. L; Seifert, K. A; Huhndorf, S; Robert, V; Spouge, J. L.; Levesque, C. A. (2012) Nuclear ribosomal internal transcribed spacer (ITS) region as a universal DNA barcode marker for Fungi. PNAS. 109[16], 62416246. https://doi.org/10.1073/pnas.1117018109

29. Mejía, E.; Tobón, J. I.; Osorno, L.; Osorio, W. (2015) Mineralogical characterization of urban construction and demolition waste: potential use as a nutrient source for degraded soils. WIT Transactions on Ecology and The Environment. 194, 399-413. https://doi.org/10.2495/ SC150351

30. Tanaca, H. K.; Dias, C. M. R.; Gaylarde, C. C.; John, V. M.; Shirakawa, M. A. (2011) Discoloration and fungal growth on three fiber cement formulations exposed in urban, rural and coastal zones. Build. Environ. 46[2], 324-330. https:// doi.org/10.1016/j.buildenv.2010.07.025

31. Tobón, J. I.; Angel, E.; Gomez, V. (2006) Medellín behavior of concretes elaborated with different stony aggregates of the surroundings of medellin. DYNA. 74[152], 251-262. 
32. Puente, M. E.; Li, C. Y.; Bashan, Y. (2004) Microbial populations and activities in the rhizoplane of rockweathering desert plants. II. Growth promotion of cactus seedlings. Plant Biol. 6[5], 643-650. https://doi. org $/ 10.1055 / \mathrm{s}-2004-821101$

33. Collignon, C.; Uroz, S.; Turpault, M. P.; Frey-Klett, P. (2011) Seasons differently impact the structure of mineral weathering bacterial communities in beech and spruce stands. Soil Biol. Biochem. 43[10], 2012-2022. https://doi. org/10.1016/j.soilbio.2011.05.008.

34. Lian, B.; Chen, Y.; Zhu, L.; Yang, R. (2008) Effect of Microbial Weathering on Carbonate Rocks. Earth Sci. Front. 15[6]; 90-99. https://doi.org/10.1016/S1872-5791(09)60009-9
35. Uroz, S.; Oger, P.; Lepleux, C.; Collignon, C.; FreyKlett, P.; Turpault, M. P. (2011) Bacterial weathering and its contribution to nutrient cycling in temperate forest ecosystems. Res. Microbiol. 162[9], 821-831. https://doi. org/10.1016/j.resmic.2011.01.013

36. Lepleux, C.; Uroz, S.; Collignon, C.; Churin, J. L.; Turpault, M. P.; Frey-Klett, P. (2013) A short-term mineral amendment impacts the mineral weathering bacterial communities in an acidic forest soil. Res. Microbiol. 164[7],. 729-739. https://doi.org/10.1016/j.resmic.2013.03.022

37. Wallace, K. J. (2007) Classification of ecosystem services: Problems and solutions. Biol. Conserv. 139[3-4], 235-246. https://doi.org/10.1016/j.biocon.2007.07.015 